\title{
Cactus Weevils, Gerstaeckeria hubbardi (LeConte) and Gerstaeckeria fasciata Pierce (Insecta: Coleoptera: Curculionidae) ${ }^{1}$
}

Robert E. Woodruff ${ }^{2}$

\section{Introduction}

There are 18 species in the weevil genus Gerstaeckeria in North America, north of Mexico. Of these, only G. hubbardi (LeConte) and G. fasciata Pierce, feed on cacti of the genus Opuntia in Florida.

\section{Synonymy}

Gerstaeckeria hubbardi (LeConte)

Acalles dilatatus Casey, 1895

Acalles hubbardi LeConte, 1880

Gerstaeckeria fasciata Pierce, 1912

(from O'Brien 1970)

\section{Distribution}

The genus is known from Cuba, Guadeloupe, Guatemala, Haiti, Mexico (Arnett 1962, Kissinger 1964). In the U.S. and Canada, the genus is known in all regions except in eastern Canada, the northeast

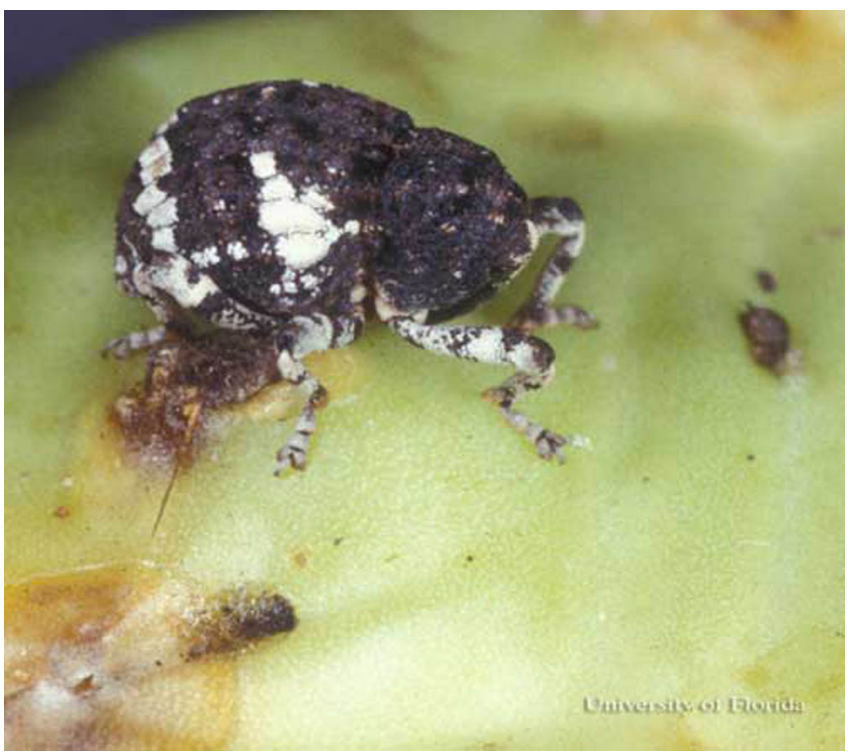

Figure 1. Adult Gerstaeckeria hubbardi (LaConte), a cactus weevil. Head at right. Credits: Lyle J. Buss, University of Florida

U.S., and states in the Great Lakes region (Arnett 2000). G. hubbardi and G. fasciata are the only species found in the eastern U.S. (O'Brien 1970)

1. This document is EENY-382 (IN688), originally published as DPI Entomology Circular 82 (updated for this publication), one of a series of Featured Creatures from the Entomology and Nematology Department, Florida Cooperative Extension Service, Institute of Food and Agricultural Sciences,

University of Florida. Published: July 2006. This document is also available on Featured Creatures Website at http://creatures.ifas.ufl.edu. Please visit the EDIS Website at http://edis.ifas.ufl.edu.

2. Robert E. Woodruff, Florida Department of Agriculture and Consumer Services, Division of Plant Industry, Gainesville, FL.

The Institute of Food and Agricultural Sciences (IFAS) is an Equal Opportunity Institution authorized to provide research, educational information and other services only to individuals and institutions that function with non-discrimination with respect to race, creed, color, religion, age, disability, sex, sexual orientation, marital status, national origin, political opinions or affiliations. U.S. Department of Agriculture, Cooperative Extension Service, University of Florida, IFAS, Florida A. \& M. University Cooperative Extension Program, and Boards of County Commissioners Cooperating. Larry Arrington, Dean 
G. hubbardi is known in Alabama, Georgia and Florida (Peck and Thomas 1998). It probably occurs throughout peninsular Florida.

G. fasciata was originally described from Buck Key, Florida. All known localities are in Monroe County, and the species may be confined to the Florida Keys, associated with one or more of the southern species of Opuntia.

\section{Description}

These are medium sized weevils with $G$. hubbardi 7.5 to $9.5 \mathrm{~mm}$, and G. fasciata 5.0 to $5.8 \mathrm{~mm}$ in length (O'Brien 1970). Beaks are concealed in a groove. Surfaces are coated with minute scales which vary in color from white through shades of brown to black. These scales can be rubbed off and the pattern is somewhat variable. The general pattern of white humeral angles and a broad light colored apical band is similar in many species, including the two Florida ones.

\section{Biology}

All members of this genus are known to breed in Opuntia cacti, although there has been little specific data published on their life histories. Brief notes on western species were published by Pierce (1907, 1912), and Hunter et al. (1912).

The adults feed externally on the pads, often hiding beneath those on the ground during the day. Both Florida species appear to be more active at night. When disturbed they drop to the ground, fold up the legs, and feign death. They are difficult to distinguish from their surroundings.

The larva of G. hubbardi feeds within the pads, producing semicircular scars, leaving the epidermis intact. The single pad is usually killed and sometimes separates from the main plant. Hunter et al. (1912) suggested that the weevil appears "...to follow the work of Melitara prodenialis Walker." This is a moth of the family Pyralidae, the larvae of which feed on Opuntia in Florida.

The pupal cell of G. hubbardi is formed near the base of the pad and is composed of sand grains cemented around a chamber of larval feces and

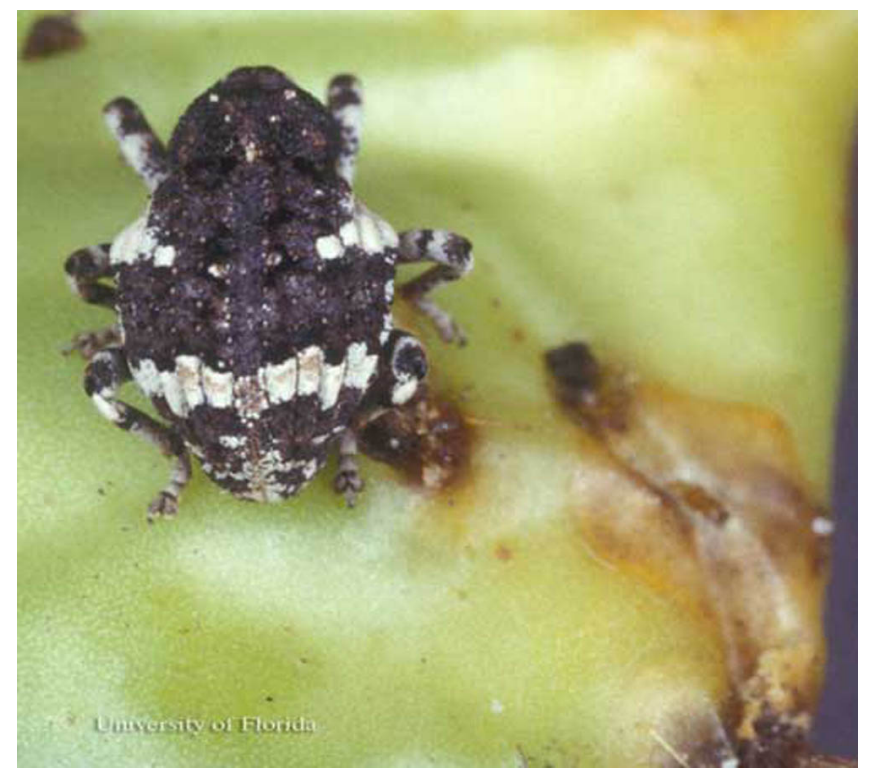

Figure 2. Adult Gerstaeckeria hubbardi (LaConte), a cactus weevil. Head at top. Credits: Lyle J. Buss, University of Florida

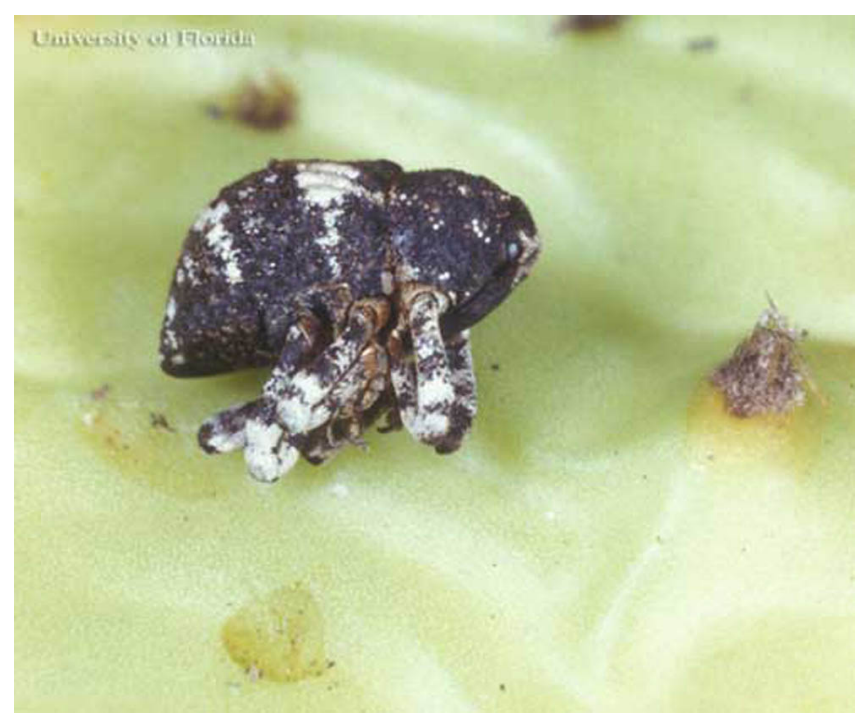

Figure 3. Adult Gerstaeckeria hubbardi (LaConte), a cactus weevil, feigning death. Head to right. Credits: Lyle J. Buss, University of Florida

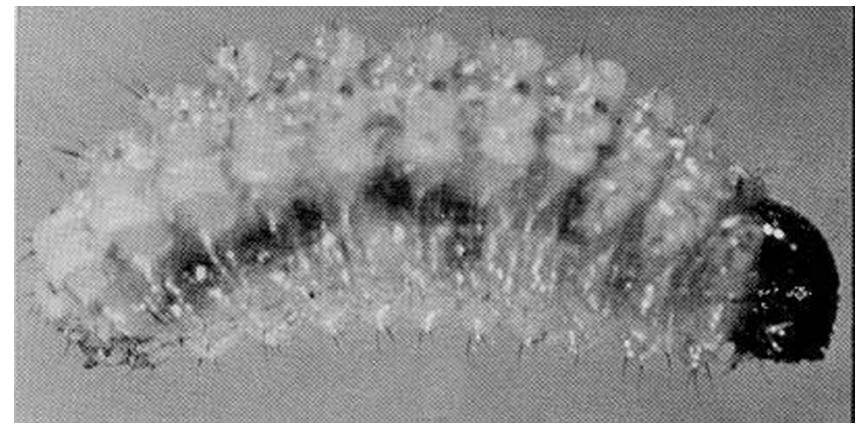

Figure 4. Larva of Gerstaeckeria hubbardi (LaConte), a cactus weevil. Credits: Division of Plant Industry 


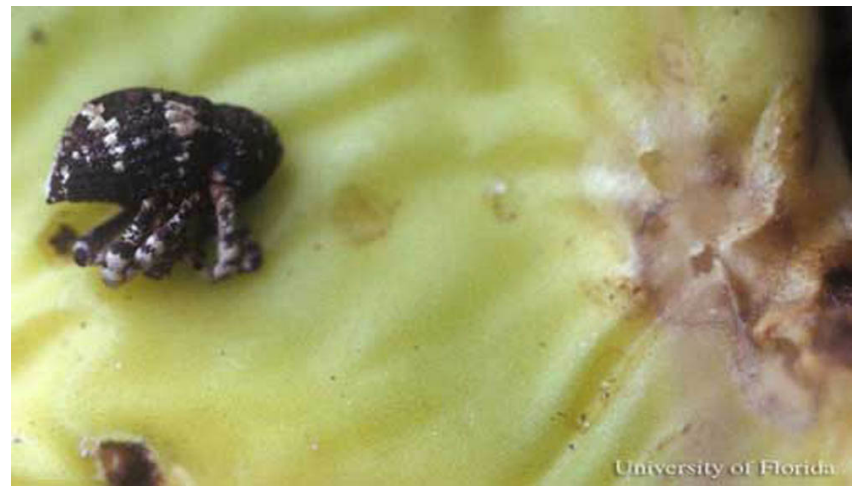

Figure 5. Adult Gerstaeckeria hubbardi (LaConte), a cactus weevil, near larval damage (right). Credits: Lyle J. Buss, University of Florida

decaying cactus. The adult may remain in the cell for some time before emerging. Adults have been collected in Florida every month except January, July, August, September, and October. Most of the records are for April, May, and June.

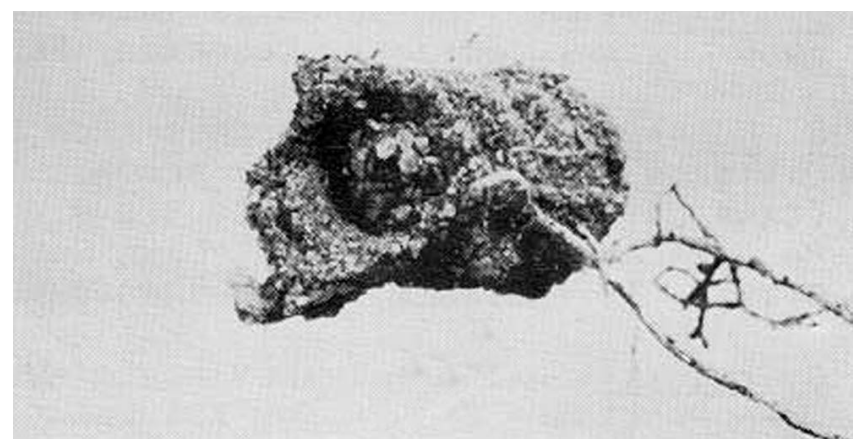

Figure 6. Pupal cell of Gerstaeckeria hubbardi (LaConte), a cactus weevil. Credits: Division of Plant Industry

\section{Key to the Florida Species of Gerstaeckeria}

1. Elytral color pattern predominantly black and white; length 7.5 to $9.5 \mathrm{~mm}$; elytra nearly twice as wide as pronotum; peninsular Florida .... hubbardi

$1 '$. Elytral color black with white humeral spots and caramel or tan subapical band; length 5.0 to $5.8 \mathrm{~mm}$; elytra about 1.5 times wider than pronotum; Florida Keys (Monroe County) . . . . fasciata

\section{Hosts}

All known species are associated with cacti of the genus Opuntia (sens. lat.). G. hubbardi was listed by Pierce (1912) from Opuntia vulgaris. However, Small (1925) did not list this species from Florida although he does list approximately 13 other species

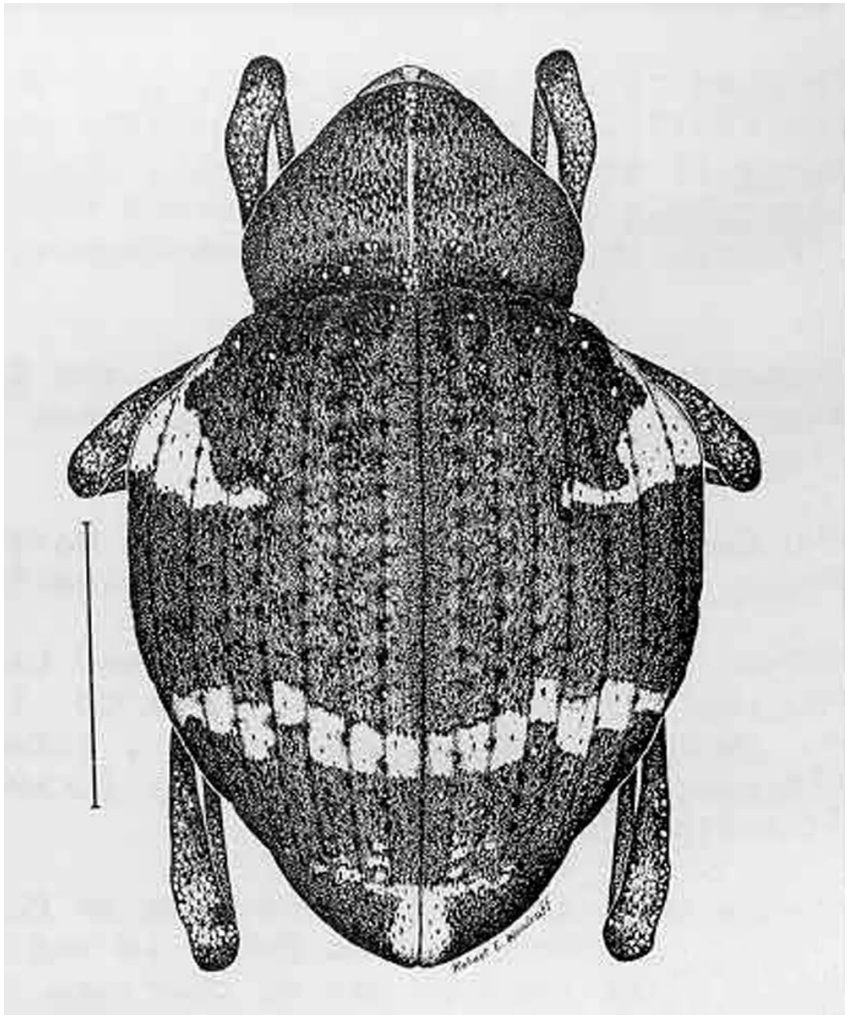

Figure 7. Adult Gerstaeckeria hubbardi, showing cryptic coloration

of Opuntia from within the range of G. hubbardi. At Gainesville, the author found it on the "joe jumper," probably $O$. tracyii. The localities where $G$. fasciata was found are within the distribution of at least three species of Opuntia (dillenii, keyensis, stricta).

The genus Opuntia is a large and taxonomically confusing one, with the status of several Florida forms somewhat in doubt. However, it is likely that $G$. hubbardi feeds on several species. It is possible that G. fasciata, with its restricted distribution, is more host specific.

\section{Management}

Since most members of the genus Opuntia are considered weeds or undesirable plants, these weevils are therefore beneficial. However, their damage has not been noted severe enough to suggest their usefulness in biological control. Additional life history studies may suggest their value in combination with other cactus-feeding insects. 


\section{Selected References}

Arnett Jr RH. 2000. American Insects: A Handbook of the Insects of America North of Mexico. CRC Press. Boca Raton. 1003 pp.

Blatchley WS, Leng CW. 1916. Rhynchophora or weevils of North Eastern America. Nature Publishing Co., Indianapolis. 682 pp.

Fisher WS. 1925. New cactus weevil from Texas. Journal of the Washington Academy of Sciences 15: 425-426.

Hunter WD, Pratt FC, Mitchell JD. 1912. The principal cactus insects of the United States. USDA Bureau of Entomology Bulletin 113: 1-71.

Kissinger DG. 1964. Curculionidae of America north of Mexico; a key to the genera. Taxonomic Publishing, So. Lancaster, MA. 143 pp.

O'Brien CW. 1970. Taxonomic revision of the genus Gerstaeckeria north of Mexico (Coleoptera: Curculionidae). Annals of the Entomological Society of America. 63: 255-272.

Peck SB, Thomas MC. (1998). Family Curculionidae. A Distributional Checklist of the Beetles (Coleoptera) of Florida. http://www.fscadpi.org/coleoptera/mike/curculio.htm (29 June 2006).

Pierce WD. 1907. On the biologies of the Rhynchophora of North America. Nebraska State Board of Agriculture Zoological Report (1907): 247-319.

Pierce WD. 1912. Systematic notes and description of some weevils of economic or biological importance. Proceedings of the U.S. National Museum 42: 155-170.

Small JK. 1925. Gathering cacti in the eastern coastal plain. Journal of the New York Botanical Gardens 26: 241-258, 265-285. 